\title{
The Productivity of Maize and Sorghum Cultivated in Organic System
}

\author{
Jerzy Księżak and Jolanta Bojarszczuk* \\ Department of Forage Crop Production, Institute of Soil Science and Plant Cultivation - State Research Institute, Poland
}

Submission: March 22, 2019; Published: April 04, 2019

*Corresponding author: Jolanta Bojarszczuk, Department of Forage Crop Production, Institute of Soil Science and Plant Cultivation - State Research Institute, Puławy, Poland

\section{Abstract}

The aim of the study was the assessment of productivity of maize and sorghum in depend on cultivation method and fertilizer dose cropped in ecological system. The study was conducted at the Institute of Soil Science and Plant Cultivation - Agricultural Experimental Station Grabów [Poland]. The first order factor was cultivation method and the second factor were composted manure dose. The study showed that the use of mechanical weed control in the cultivation of maize and sorghum resulted in a significant increase in the fresh matter yield compared to the control treatment. Increasing composted manure dose positively affected the yield of both plant species. The yield of fresh matter of maize fertilized with a dose of $20 \mathrm{t}$ ha- 1 in the treatment without weed control, was by about $15 \%$ lower than yield of maize fertilized with a twice higher manure dose. Maize plants that were not cultivated by mechanical methods contained less dry matter, regardless of the composted manure dose, compared to mechanically treated plants. The dry matter content in cobs was much higher than in whole maize plants. Much less dry matter content in the cobs of maize not mechanically cultivated than in the cobs of mechanically cultivated plants. The share of seeds in the maize cob in the control treatment, was about $15 \%$ lower than in the mechanically-treated plants. An increase in organic fertilization dose, had no effect on the share of cob in maize plant structure, while the cultivation method had significant influence of this feature.

Keywords: Sorghum; Maize; Manure dose, Brush weeder; Weeding hoe; Hiller; Weed control

\section{Introduction}

An important element of organic farms is animal production. Most often these are ruminants for which roughage should be produced from plant species grown on the farm. Protein feed may be produced from legumes, mixtures of legumes with grasses and mixtures of legumes with cereals. However, in order to ensure an adequate amount of energy feed, which is very important in dairy cattle feeding, there is often a need to grow maize or sorghum [1]. Green fodder can be fed, but they are most often used for the production of silage, which provides good quality fodder.

Sorghum is not a very popular species in conditions in Poland. In the past, attempts were made to cultivate this species as a secondary crop (harvested in one or two cuts), after winter rye [2-4]. This species is more resistant to drought than maize [5]. According to Meeske \& Basson [6], lower drought resistance is results from the much higher efficiency of soil water absorption compared to cereals. It is characterized by low transpiration coefficient and deep root system, collecting water from deeper soil layers $[7,8]$. In addition, it has ability to yielding better than maize $[9,10]$.
Sorghum and maize are characterized by high dynamics of nutrient uptake and accumulation. At the beginning of the growing season, both species produce stems and leaves, and maize also cob cores, in which almost all the fibre is accumulated. In the second growing season, occurs an intensive accumulation of easily assailable carbohydrates, mainly starch in the grains. The feed value of these plant species increases with their development. The most valuable part of maize is the cob. Due to the large amount of soluble sugars, maize and sorghum are an excellent silage raw material, the value of which is determined primarily by the starch content of the grains.

Due to the sowing in wide rows and their slow initial growth, sorghum and maize are easily wedded, and the weeds occurring from the emergence to 8-10 leaf stage, limit their growth the strongest [11-14]. According to Rola \& Rola [15], yield reductions caused by weed infestation of maize can be as much as 70\%, and according to Skrzypczak [16], under a high weed occurrence, as much as $90 \%$. Literature on the mechanical weed control of maize and sorghum [17], is insufficient. According to Waligóra et al. [18], in the cultivation of sugar corn, the mechanical weed control efficiency was significantly lower than the 
chemical method, strongly limiting only the occurrence of Echinochloa crus-galli. However, Wilson [19] reports that mechanical weed control can destroy about $87 \%$ of the weeds occurring in maize crops. It is also important to apply the proper fertilizer to obtain high yields with good quality silage raw material.

The aim of the study was the assessment of productivity of maize and sorghum in depend on cultivation method and fertilizer dose cropped in ecological system.

\section{Materials and Method}

The study was conducted at the Institute of Soil Science and Plant Cultivation - Agricultural Experimental Station Grabów

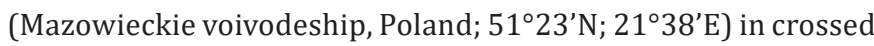
subblock method, in four replications. The first order factor was: cultivation method:

a) Control object (without weed control);

b) Brush weeder, three times during the vegetation season: after emergence of maize or sorghum (1-2 leaves), 4-6 leaves of maize or sorghum and at a plant height of $25-30 \mathrm{~cm}$;

c) Weeding hoe, three times during the season: after emergence of maize or sorghum (1-2 leaves), 4-6 leaves of maize or sorghum and at a plant height of $25-30 \mathrm{~cm}$;

d) Brush weeder and hiller, two times during the season: after emergence of maize or sorghum (1-2 leaves) and 4-6 leaves of maize or sorghum.

The second factor included dose of natural fertilization: 20 and $40 \mathrm{t}$ composted manure per 1 ha.

The experiment was conducted on the good rye soil complex, class III a. The concentration of available forms of nutrients in the soil amounted to (in mg per $100 \mathrm{~g}$ of the soil): P - 11.5 - 13.5, $\mathrm{K}-12.6$ - 13.1, Mg - 4.1-4.8. The content of humus amounted to $1.30-1.42 \%$. Soil $\mathrm{pH}$ determined in $1 \mathrm{n} \mathrm{KCl}$ was 6.0-6.3 (in depend on the year of the study).
Mineral fertilization was not used. Sowing of maize was carried out from 27 to 30 April, sorghum from 10 to 18 of May. Maize harvest was carried out in the second decade of September, and sorghum in the third decade of October. Before harvesting, the plant height was determined on 10 randomly chosen plants from each plot. The dry matter content of the whole plant, the structure of the maize plant (share of stem, seeds, corncob and covering leaf) and the height of the maize cob were determined. After harvesting, the yield of fresh and dry matter was determined.

The impact of the tested experimental factors on the observed characteristics were assessed using the analysis of variance, setting Tukey's confidence half-intervals at significance level of $\alpha=0.05$.

\section{Results and Discussion}

The yields of fresh and dry matter of maize and sorghum were significantly influenced by the applied doses of organic fertilizers, weed control methods, and by the course of weather conditions during the growing season (Table 1). In 2011, in the period from April to September, a higher air temperature was recorded compared to the than the average temperature from the multi-years. The total precipitation from March to June was much lower than the multi-years average, but very high precipitation in July created favorable conditions for the growth of both species. In 2012, a slightly higher air temperature was recorded compared to the average of the multi-years. Total precipitation from March to September was like the precipitation from the multi-years average, only a small amount of precipitation being recorded in the third decade of June and the first decade of July. On the other hand, in 2013 a small amount of precipitation occurred in July and August, caused to reducing the availability of nutrients contained in natural fertilizers. As a result, the yields of both assessed species were significantly lower in 2013 than in the year with more precipitation.

Table 1: Course of weather conditions during the vegetation periods.

\begin{tabular}{|c|c|c|c|c|c|c|c|c|}
\hline \multirow{2}{*}{ Specification } & \multirow{2}{*}{ Year } & \multicolumn{6}{|c|}{ Month } & \multirow{2}{*}{ Sum (IV-IX) } \\
\hline & & IV & $\mathbf{V}$ & VI & VII & VIII & IX & \\
\hline \multirow{3}{*}{ Rainfalls (mm) } & 2011 & 35.9 & 74.5 & 52.4 & 298.8 & 35.6 & 3.6 & 500.8 \\
\hline & 2012 & 37.8 & 36.5 & 54.3 & 81.6 & 64.2 & 21.8 & 296.2 \\
\hline & 2013 & 29.9 & 112 & 116.3 & 20.8 & 11.8 & 63.9 & 354,7 \\
\hline Rainfalls mean from multi-years (mm) & & 39 & 57 & 71 & 84 & 75 & 50 & 376 \\
\hline \multirow{3}{*}{ Temperature $\left({ }^{\circ} \mathrm{C}\right)$} & 2011 & 10.3 & 13.9 & 18.5 & 18.4 & 18.8 & 14.7 & 15.8 \\
\hline & 2012 & 9.6 & 15.3 & 17.7 & 20.9 & 18.8 & 14.5 & 16.1 \\
\hline & 2013 & 8.3 & 15.3 & 18.6 & 19.7 & 19.2 & 11.8 & 92,9 \\
\hline Temperature mean from multi-years $\left({ }^{\circ} \mathrm{C}\right)$ & & 7.7 & 13.4 & 16.7 & 18.3 & 17.3 & 13.2 & 14.4 \\
\hline
\end{tabular}

Source: Bulletin of State Hydrological and Meteorological Service IMGW-PIB.

${ }^{*}$ Average from years 1871-2000. 
In the years of the study, fresh and dry matter yields of sorghum was higher than yields of maize (Table 2). The yield of fresh matter in the control treatment (with no weed control) was higher by about $67 \%$, while in the treatments where mechanical weed control was applied, by about $35 \%$. The difference in dry matter yield was lower than in the case of fresh matter yield and amounted to $54 \%$ in the control treatment, and on average about $14 \%$ for the 3 methods limiting weed infestation. The results obtained by Camargo \& Hubbard [10], Krieg \& Lascano [9] also indicate that sorghum has a higher yield potential than maize. The use of mechanical weed control measures in the cultivation of both species resulted in a significant increase in yields compared to the control treatment (Table 2). The increase in the fresh matter yield of maize, regardless of the organic fertilizer dose, was about $92 \%$, while of sorghum at about $54 \%$. In addition, the increase in the yield of maize fertilized with a dose of $20 \mathrm{t} \mathrm{ha}^{-1}$ was higher than in the treatments with dose $40 \mathrm{t} \mathrm{ha}^{-1}$, while in the case of sorghum, the differences were very similar. Drzewiecki \& Pietryga [20], in the conventional system after the application of herbicides, obtained a statistically significant increase in maize grain yield in relation to the control treatment. Gołębiowska [21-23], under such conditions, demonstrated that the use of herbicides allowed obtaining significantly higher grain yields compared to the treatments without weed control. According to Waligóra et al. [18], sugar corn yielded better after mechanical and chemical weed control than after the mechanical one.

Table 2: Fresh and dry matter yields of maize and sorghum depending on cultivation method and doses of organic fertilization (ton ha-1).

\begin{tabular}{|c|c|c|c|c|c|c|c|c|}
\hline \multirow{4}{*}{ Cultivation Method } & \multicolumn{4}{|c|}{ Fresh Matter Yields } & \multicolumn{4}{|c|}{ Dry Matter Yields } \\
\hline & \multicolumn{2}{|c|}{ Maize } & \multicolumn{2}{|c|}{ Sorghum } & \multicolumn{2}{|c|}{ Maize } & \multicolumn{2}{|c|}{ Sorghum } \\
\hline & \multicolumn{8}{|c|}{ Doses of Composted Manure $\left(\mathrm{t} \cdot \mathrm{ha}^{-1}\right)$} \\
\hline & 20 & 40 & 20 & 40 & 20 & 40 & 20 & 40 \\
\hline Control & 16 & 18.4 & 28 & 29.7 & 5.3 & 6.1 & 8.5 & 9.2 \\
\hline Brush weeder & 32.4 & 34.5 & 40.8 & 43.3 & 11.4 & 12.5 & 10.7 & 13.1 \\
\hline Weeding hoe & 31.6 & 33 & 43.9 & 45.1 & 11.4 & 12 & 15.6 & 13.8 \\
\hline Brush weeder + hiller & 32.3 & 33.8 & 46.1 & 48.2 & 12.1 & 12.3 & 12.9 & 14.9 \\
\hline \multicolumn{9}{|c|}{$\operatorname{LSD}(\alpha=0.05)$ for: } \\
\hline Doses of composted manure (A) & \multicolumn{2}{|c|}{ n.s. } & \multicolumn{2}{|c|}{ n.s. } & \multicolumn{2}{|c|}{0.635} & \multicolumn{2}{|c|}{ n.s. } \\
\hline Cultivation method (B) & \multicolumn{2}{|c|}{6.543} & \multicolumn{2}{|c|}{2.807} & \multicolumn{2}{|c|}{1.336} & \multicolumn{2}{|c|}{2.445} \\
\hline $\mathrm{B} / \mathrm{A}$ & \multicolumn{2}{|c|}{ n.s. } & \multicolumn{2}{|c|}{ n.s. } & \multicolumn{2}{|c|}{ n.s. } & \multicolumn{2}{|c|}{ n.s. } \\
\hline $\mathrm{A} / \mathrm{B}$ & \multicolumn{2}{|c|}{ n.s. } & \multicolumn{2}{|c|}{ n.s. } & \multicolumn{2}{|c|}{ n.s. } & \multicolumn{2}{|c|}{ n.s. } \\
\hline
\end{tabular}

Source: own study.

The yields of fresh matter (average of 3-years of the study) of maize fertilized with a dose of $20 \mathrm{t} \mathrm{ha}^{-1}$ in the treatment with no weed control, were about $15 \%$ lower than in the treatments fertilized with a dose of $40 \mathrm{tha}^{-1}$ (Table 2). On the other hand, in the treatments, where mechanical weed control was applied, these differences were much smaller and amounted to about $5.6 \%$. The yields of fresh matter of sorghum fertilized the same doses, in the treatment in which weeds were not controlled, were lower by about $6 \%$, while on those where mechanical weed controls was applied, they were lower by $4.3 \%$. In the previous studies Księżak et al. [24], found that in a year with limited precipitation in July, the yield of dry matter of sorghum and maize fertilized with a dose of $20 \mathrm{t} \mathrm{ha}^{-1}$ were similar to those fertilized with a higher dose - 40t ha-1. Księżak \& Machul [25] reported that increasing the nitrogen dose from 120 to $160 \mathrm{~kg}$ per ha in sorghum cropped in conventional system, causes a significant increase in the yield of fresh matter. According to these authors, the dry matter yield was slightly different, and the development stage of sorghum, which did not reach the recommended milkdough stage (tasseling stage), had a significant influence on the development stage of sorghum. According to Gourley and Luska after Mucha \& Brzóska [26], the achievement of this stage by plants is possible to replace maize cultivation for silage. In their own studies, the yield of dry matter sorghum was lower than the maximum recorded in their experiments of Mucha \& Brzóska [26]. Sowiński \& Podkowa-Liszka [27], found that increasing in nitrogen doses caused a slight tendency of yield increase only. Similarly, Geng et al. [28] did not obtain an increase in the sorghum yield after increasing the nitrogen rate above $100 \mathrm{~kg}$ ha $^{-1}$. In other studies of Księżak et al. [29] found that increasing nitrogen dose from 80 to $160 \mathrm{~kg} \mathrm{~N} \mathrm{ha}^{-1}$ caused significant increase in sorghum yields and was recorded only in the year of less favorable weather conditions during the growing season.

During the experiment, sorghum plants contained less dry matter than maize plants. The content of dry matter in the whole maize plants was not very diversified by the dose of organic fertilizer, as well as by the cultivation method (Table 3). A smaller amount of this component, not depending on the dose of composted manure, was recorded in maize plants, cultivated without mechanical weed control, as compared to plants mechanically cultivated. The cultivation method had a 
slight effect on the dry matter content in sorghum plants (no significant differences) (Table 3). The dry matter content in maize cobs was much higher than in the whole plants. Moreover, cobs of maize without mechanical weed control contented much less dry matter than those of plants cultivated mechanically (Table 3).

Table 3: Dry matter content in plants and cob of maize and dry matter content in sorghum plants depending on cultivation method and doses of organic fertilization (\%).

\begin{tabular}{|c|c|c|c|c|c|c|}
\hline \multirow{3}{*}{ Cultivation Method } & \multicolumn{2}{|c|}{$\begin{array}{c}\text { Dry Matter Content in Plants } \\
\text { Maize }\end{array}$} & \multicolumn{2}{|c|}{$\begin{array}{c}\text { Dry Matter Content in Cob } \\
\text { Maize }\end{array}$} & \multicolumn{2}{|c|}{$\begin{array}{c}\text { Dry Matter Content in Plants } \\
\text { Sorghum }\end{array}$} \\
\hline & \multicolumn{6}{|c|}{ Doses of Composted Manure ( $\mathrm{t} \mathrm{ha}^{-1}$ ) } \\
\hline & 20 & 40 & 20 & 40 & 20 & 40 \\
\hline Control & 34.4 & 34.5 & 41.8 & 41.8 & 29.5 & 29.6 \\
\hline Brush weeder & 35.6 & 36.2 & 49.4 & 49 & 29.2 & 29.2 \\
\hline Weeding hoe & 36.1 & 36.6 & 49.2 & 50 & 28.6 & 29.6 \\
\hline Brush weeder + hiller & 37.2 & 36.5 & 50.5 & 49.8 & 29.7 & 30.2 \\
\hline \multicolumn{7}{|c|}{$\operatorname{LSD}(\alpha=0.05)$ for: } \\
\hline Doses of composted manure (A) & \multicolumn{2}{|c|}{ n.s. } & \multicolumn{2}{|c|}{ n.s. } & \multicolumn{2}{|c|}{ n.s. } \\
\hline Cultivation method (B) & \multicolumn{2}{|c|}{ n.s. } & \multicolumn{2}{|c|}{0.583} & \multicolumn{2}{|c|}{ n.s. } \\
\hline $\mathrm{B} / \mathrm{A}$ & \multicolumn{2}{|c|}{ n.s. } & \multicolumn{2}{|c|}{ n.s. } & \multicolumn{2}{|c|}{ n.s. } \\
\hline $\mathrm{A} / \mathrm{B}$ & \multicolumn{2}{|c|}{ n.s. } & \multicolumn{2}{|c|}{ n.s. } & \multicolumn{2}{|c|}{ n.s. } \\
\hline
\end{tabular}

Source: own study.

Plants of both evaluated species characterized the lowest height in the control treatment, where no weed control was applied, regardless of the dose of composted manure (Table 4). As maize as sorghum fertilized with $40 \mathrm{t}$ ha- 1 of manure were higher than plants fertilized with a $50 \%$ lower dose of composted manure, regardless of the method of weed control. In addition, sorghum plants were higher than maize plants, not depending on the dose of organic fertilizer and weed control. Maize formed the cobs the lowest in the control treatment, where no weed control was applied (Table 4). The cultivation method had effect on height of maize cob set on the plant and height of maize plant (significance differences). The increase in the dose of organic fertilization had no significant impact on this feature. As dose of composted manure as cultivation method affected on height of sorghum plant

Table 4: The height of maize and sorghum plants and height of cob set depending on cultivation method and doses of organic fertilization (cm).

\begin{tabular}{|c|c|c|c|c|c|c|}
\hline \multirow{3}{*}{ Cultivation Method } & \multicolumn{2}{|c|}{ Height of Maize Plant } & \multicolumn{2}{|c|}{ Height of Maize Cob Set } & \multicolumn{2}{|c|}{ Height of Sorghum Plant } \\
\hline & \multicolumn{6}{|c|}{ Doses of Composted Manure ( $\mathrm{t} \mathrm{ha} \mathrm{a}^{-1}$ ) } \\
\hline & 20 & 40 & 20 & 40 & 20 & 40 \\
\hline Control & 146 & 152 & 65 & 69 & 201 & 210 \\
\hline Brush weeder & 215 & 214 & 85 & 85 & 244 & 260 \\
\hline Weeding hoe & 210 & 217 & 87 & 90 & 250 & 266 \\
\hline Brush weeder + hiller & 222 & 218 & 89 & 90 & 256 & 268 \\
\hline \multicolumn{7}{|c|}{$\operatorname{LSD}(\alpha=0.05)$ for: } \\
\hline Doses of composted manure (A) & \multicolumn{2}{|c|}{ n.s. } & \multicolumn{2}{|c|}{ n.s. } & \multicolumn{2}{|c|}{12.707} \\
\hline Cultivation method (B) & \multicolumn{2}{|c|}{6.46} & \multicolumn{2}{|c|}{17.034} & \multicolumn{2}{|c|}{10.046} \\
\hline $\mathrm{B} / \mathrm{A}$ & \multicolumn{2}{|c|}{ n.s. } & \multicolumn{2}{|c|}{ n.s. } & \multicolumn{2}{|c|}{ n.s. } \\
\hline $\mathrm{A} / \mathrm{B}$ & \multicolumn{2}{|c|}{ n.s. } & \multicolumn{2}{|c|}{ n.s. } & \multicolumn{2}{|c|}{ n.s. } \\
\hline
\end{tabular}

Source: own study.

Maize plant structure was depending on cultivation method. In treatments with mechanical weed control, stems, leaves, and tassel constituted a smaller percentage in the maize plant structure than in the control treatment (Table 5). The increase in organic fertilization from 20 to $40 \mathrm{t} \mathrm{ha}^{-1}$ did not affect the share of the cob in the plant structure, regardless of the applied weed control method. 


\section{International Journal of Environmental Sciences \& Natural Resources}

Table 5: Structure of maize plant depending on cultivation method and doses of organic fertilization (\%).

\begin{tabular}{|c|c|c|c|c|}
\hline \multirow{3}{*}{ Cultivation Method } & \multicolumn{2}{|c|}{ Stem + Leaves } & \multicolumn{2}{|c|}{ Cob } \\
\hline & \multicolumn{4}{|c|}{ Doses of Composted Manure ( $\mathrm{t} \mathrm{ha}^{-1}$ ) } \\
\hline & 20 & 40 & 20 & 40 \\
\hline Control & 69 & 68 & 31 & 32 \\
\hline Brush weeder & 54 & 53 & 46 & 47 \\
\hline Weeding hoe & 53 & 52 & 47 & 48 \\
\hline Brush weeder + hiller & 53 & 53 & 47 & 47 \\
\hline \multicolumn{5}{|l|}{$\operatorname{LSD}(\alpha=0.05)$ for: } \\
\hline $\begin{array}{l}\text { Doses of composted } \\
\text { manure }(A)\end{array}$ & n.s. & n.s. & & \\
\hline Cultivation method (B) & 10.19 & 3.413 & & \\
\hline $\mathrm{B} / \mathrm{A}$ & n.s. & n.s. & & \\
\hline $\mathrm{A} / \mathrm{B}$ & n.s. & n.s. & & \\
\hline
\end{tabular}

Source: own study.

The cob, especially the seeds, are the most valuable part of the maize plant, which have a fundamental influence on the quality of the silage raw material. The share of seeds in the cob structure in the treatment without weed control, was about $15 \%$ lower than in those mechanically-treated (Table 6). A small effect of increasing the dose of organic fertilizer on the share of seeds in the cob, was noted. Moreover, various mechanical cultivation method limiting the occurrence of weeds had a relatively small influence on the structure of the cob (statistically significant differences). The share of corncob in the cob was about 2 times higher than covering leaves. The dose of organic fertilization had no effect on the share of corncob and covering leaf.

Table 6: Cob structure of maize depending on cultivation method and doses of organic fertilization (mean for 2011-2013) (\%).

\begin{tabular}{|c|c|c|c|c|c|c|}
\hline \multirow{4}{*}{ Cultivation Method } & \multicolumn{6}{|c|}{ Specification } \\
\hline & \multicolumn{2}{|c|}{ Seeds } & \multicolumn{2}{|c|}{ Corncob } & \multicolumn{2}{|c|}{ Covering Leaf } \\
\hline & \multicolumn{6}{|c|}{ Doses of Composted Manure ( $t$ ha-1) } \\
\hline & 20 & 40 & 20 & 40 & 20 & 40 \\
\hline Control & 58.6 & 59.6 & 25.4 & 25.3 & 16 & 15.1 \\
\hline Brush weeder & 73.9 & 73.9 & 17.4 & 15.7 & 8.7 & 10.4 \\
\hline Weeding hoe & 74.9 & 73.9 & 16.3 & 16.9 & 8.8 & 9.2 \\
\hline Brush weeder + hiller & 74.6 & 75.7 & 16.7 & 15.3 & 8.7 & 9 \\
\hline \multicolumn{7}{|l|}{$\operatorname{LSD}(\alpha=0.05)$ for: } \\
\hline Doses of composted manure (A) & \multicolumn{2}{|c|}{ n.s. } & \multicolumn{2}{|c|}{ n.s. } & \multicolumn{2}{|c|}{ n.s. } \\
\hline Cultivation method (B) & \multicolumn{2}{|c|}{0.98} & \multicolumn{2}{|c|}{1.318} & \multicolumn{2}{|c|}{4.07} \\
\hline $\mathrm{B} / \mathrm{A}$ & \multicolumn{2}{|c|}{ n.s. } & \multicolumn{2}{|c|}{ n.s. } & \multicolumn{2}{|c|}{ n.s. } \\
\hline $\mathrm{A} / \mathrm{B}$ & \multicolumn{2}{|c|}{ n.s. } & \multicolumn{2}{|c|}{ n.s. } & \multicolumn{2}{|c|}{ n.s. } \\
\hline
\end{tabular}

Source: own study.

\section{Conclusion}

a) The yield of sorghum was higher than yield of maize, regardless the weed control method. The use of mechanical weed control in the cultivation of maize and sorghum resulted in a significant increase in the fresh matter yield compared to the control treatment. Increasing the dose from 20 to $40 \mathrm{t} \mathrm{ha} \mathrm{a}^{-1}$ positively affected the yield of both assessed species.

b) The yield of fresh matter of maize fertilized with a dose of $20 \mathrm{t}$ ha- 1 in the treatment without weed control, was by about $15 \%$ lower than yield of maize fertilized with a twice higher dose - 40t ha-1. In the treatments with mechanical weed control, the differences were much smaller and amounted to about $5.6 \%$. The yields of sorghum fertilized with $40 \mathrm{t} \mathrm{ha}^{-1}$ in the control treatment was lower by about $6 \%$.

c) Maize plants that were not mechanically cultivated characterized less dry matter content, (regardless of the composted manure dose), compared to mechanically treated plants. The use of weed control treatments in sorghum had only a slight positive effect on the accumulation of this component. 
d) The dry matter content in cobs was much higher than in whole maize plants. Much less dry matter accumulated in the cobs of maize not mechanically cultivated than in the cobs of mechanically cultivated plants.

e) In the structure of the plant, the share of cob maize cultivated in the control treatment was much smaller than in the treatments with mechanical weed control. The increase in organic fertilization from 20 to 40 t ha-1 had no effect on the share of the cob in the plant structure, regardless of the applied weed control method.

f) The share of seeds in the maize cob in the treatments, where weeds were not controlled, was about $15 \%$ lower than in the mechanically-treated plants. An increase in organic fertilization dose, had no effect on the share of corncob in maize plant structure, while the cultivation method had significant influence of this feature.

\section{References}

1. Księżak J, Kaźmierczak J (2012a) Possibilities for the fodder production at the organic farm. Wieś Jutra 5-6: 1-3 (in Polish).

2. Hryncewicz Z, Fatyga J (1975) Research on the cultivation of hybrid grass of Sudan on a green mass. Zeszyty Naukowe AR Wrocław 109: 69-78 (in Polish).

3. Krzywiecki S, Szyszkowska A (1978) Plon i wartość pokarmowa sorga i mieszańcowej trawy sudańskiej uprawianych w plonie wtórym. Nowe Rolnictwo 14: 4-5 (in Polish).

4. Śliwiński BJ, Brzóska F (2006) History of sorghum cultivation and nutritive value of this plant in silage cultivation. Postępy Nauk Rolniczych 1: 25-37 (in Polish).

5. Ashbell G, Weinberg ZG (1999) Silage from tropical cereals and forage crops. FAO Production and protection Paper, 161. Proceedings of the FAO Electronic Conference on Tropical Silage, 1 IX-15 XII.

6. Meeske R, Basson HM (1995) Research note; maize and forage sorghum as silage crops under drought conditions. African Journal of Range \& Forage Science 12: 133-134.

7. Wright GC, Smith CG (1983) Differences between two grain sorghum genotypes in adaptation to drought stress. II. Root water uptake and water use. Australian Journal of Agricultural Research 34(6): 627-636.

8. Singh BR, Singh DP (1995) Agronomic and physiological responses of sorghum maize and pearl millet to irrigation. Field Crops Research 42(2-3): 57-67.

9. Krieg DR, Lascano RJ (1990) Sorghum. Irrigation of Agricultural Crops. American Society of Agronomy, Madison, USA, pp. 719-740.

10. Camargo MBP, Hubbard KG (1999) Drought sensitivity indices for sorghum crop. Journal of Production Agriculture 12(2): 312-316.

11. Hruszka M (2003) Effectiveness of proecological and chemical methods of weed control in fodder maize crops. Zeszyty Problemowe Postępów nauk Rolniczych 490: 81-97 (in Polish).

12. Evans SP, Knezevic SZ, Lindquist JL, Shapiro CA, Blankenship EE (2003) Nitrogen application influences the critical period for weed control in corn. Weed Science 51: 408-417.
13. Idziak R, Woźnica Z (2005) Evaluation of the effectiveness of adjuvants added to the herbicides used in maize protection. Progress in Plant Protection 45(2): 716-718 (in Polish).

14. Tański M, Idziak R (2009) Influence of weed control regulation on herbicide efficacy and grain yield of maize. Progress in Plant Protection 49(1): 349-352 (in Polish).

15. Rola J, Rola H (1987) Dynamika chwastów segetalnych na polach uprawnych. Materiały Konferencyjne. Dynamika zachwaszczenia pól uprawnych. Wrocław, 25-25.06, pp. 131-48 (in Polish).

16. Skrzypczak G (2006) The problem of weed control in corn growing is still valid. Kukurydza 1(6): 1-18 (in Polish).

17. Heydel L, Benoit M, Schiavon M (1999) Reducing atrazine leaching by integrating reduced herbicide use witch mechanical weeding in corn (Zea mays L.). European Journal of Agronomy 11: 217-225.

18. Waligóra H, Skrzypczak G, Szulc P (2009) Influence of sweet maize cultivation method on the weed infestation. Journal of Research and Applications in Agricultural Engineering 54(4): 148-151 (in Polish).

19. Wilson RG (1993) Effect of preplant tillage, post-plant cultivation and herbicides on weed density in corn (Zea mays L.). Weed Technology $7(3):$ 728-734.

20. Drzewiecki S, Pietryga J (2010) Effectiveness of the action of herbicides in divided, reduced doses, used together with the adjuvant in the cultivation of maize. Progress in Plant Protection 50(1): 297-302 (in Polish).

21. Gołębiowska H (2005) The influence of agrotechnical factors on the effectiveness of selected herbicides in the cultivation of maize. Progress in Plant Protection 45(1): 160-166 (in Polish).

22. Kierzek R, Paradowski A (2010) The possibility of propizochlor use to weed control in maize cultivation. Progress in Plant Protection 50(3): 1173-1176 (in Polish).

23. Księżak J, Magnuszewski T (2009) Evaluation of the effectiveness of weed control with propisochlor in the cultivation of maize. Progress in Plant Protection 49(1): 334-338 (in Polish).

24. Księżak J, Bojarszczuk J, Staniak M (2012b) Evaluation of yielding of sorghum growing in organic farming depending on cultivation method and doses of organic fertilization. Journal of Research and Application in Agricultural Engineering 57(4): 6-9.

25. Księżak J, Machul M (2007) Ocena plonowania sorga w zależności od sposobu siewu i poziomu nawożenia azotem. Materiały konferencyjne XV Szkoły Zimowej, Produkcja mleka i wołowiny a zdrowie człowieka, AR Kraków, Zakopane, 26.03-31. 03 2007, pp. 335-336 (in Polish).

26. Mucha S, Brzóska F (1983) Wstępne wyniki badań plonowania i składu chemicznego amerykańskich mieszańców sorga z trawą sudańska uprawianych w 1979 roku w Polsce. Roczniki Naukowe Zootechniki 10(1): 113-124 (in Polish).

27. Sowiński J, Liszka-Podkowa A (2008) Fresh and dry matter yield quantity and quality of maize (Zea mays L.) and sweet sorghum (Sorghum bicolor (L.) Moench.) on sandy soil depending on nitrogen fertilization. Acta Scientiarum Polonorum Agricultura 7(4): 105-115.

28. Geng S, Hills FJ, Johnson SS, Sah RN (1989) Potential yields and onfarm ethanol production cost of corn, sweet sorghum, fodder beet and sugar beet. Journal of Agronomy and Crop Science 162(1): 21-29.

29. Księżak J, Bojarszczuk J, Staniak M (2012c) The productivity of maize and sorghum yields of according level of nitrogen fertilization. Polish Journal of Agronomy 8: 20-28. 
Your next submission with Juniper Publishers will reach you the below assets

- Quality Editorial service

- Swift Peer Review

- Reprints availability

- E-prints Service

- Manuscript Podcast for convenient understanding

- Global attainment for your research

- Manuscript accessibility in different formats

( Pdf, E-pub, Full Text, Audio)

- Unceasing customer service

Track the below URL for one-step submission https://juniperpublishers.com/online-submission.php 